\title{
Faktor Prediksi Perforasi Apendiks pada Penderita Apendisitis Akut Dewasa di RS Al-Ihsan Kabupaten Bandung Periode 2013-2014
}

\author{
Fajar Awalia Yulianto, ${ }^{1}$ R. Kince Sakinah, ${ }^{1}$ M. Insan Kamil, ${ }^{2}$ Tri Yunis Miko Wahono ${ }^{3}$ \\ ${ }^{1}$ Bagian Ilmu Kesehatan Masyarakat Fakultas Kedokteran Universitas Islam Bandung, \\ ${ }^{2}$ Program Studi Sarjana Kedokteran Universitas Islam Bandung, \\ ${ }^{3}$ Bagian Epidemiologi Fakultas Ilmu Kesehatan Masyarakat Universitas Indonesia
}

\begin{abstract}
Abstrak
Morbiditas dan mortalitas apendisitis akut disebabkan oleh perkembangan apendisitis akut menjadi perforasi apendiks. Hal-hal yang menyebabkan kerentanan apendiks belum banyak diteliti dan belum diketahui penyebab pastinya. Tujuan penelitian ini adalah mengetahui faktor-faktor apa saja yang dapat memprediksi terjadinya perforasi apendiks. Penelitian dengan desain kasus kontrol menggunakan data sekunder berupa rekam medis penderita apendisitis akut dewasa di RS Al-Ihsan Kabupaten Bandung tahun 2013-2014 dengan jumlah kasus (perforasi apendiks) 36 kasus dan kontrol (nonperforasi) 93 kasus. Analisis data yang dilakukan meliputi deskriptif, chi-square, receiver operating characteristic, dan regresi logistik multivariat. Dua faktor prediksi yang bermakna sebagai faktor prediksi perforasi apendiks dalam analisis regresi logistik multivariat adalah suhu badan di atas $37,5^{\circ} \mathrm{C}$ dengan odds ratio (OR) 7,54 (IK 95\%: 2,01-28,33), jumlah leukosit di atas $11.500 / \mathrm{mm}^{3}$ dengan OR 12,12 (IK 95\%: 4,03-36,48). Perlu validasi pemeriksaan suhu badan di RS, penelitian lebih lanjut untuk mencari faktor prediksi lainnya, persiapan operasi segera untuk pencegahan komplikasi perforasi apendiks, dan pemberian informasi ke masyarakat bahwa sakit perut dapat bersifat gawat darurat.
\end{abstract}

Kata kunci: Apendisitis akut, faktor prediksi, perforasi apendiks

\section{Predictive Factors for Perforated Appendix in Acute Appendicitis Adult Patients in Al-Ihsan Hospital Bandung Regency 2013-2014}

\begin{abstract}
Appendix perforation is the causation for acute appendicitis morbidity and mortality. Factors that may cause appendix vulnerability has not been extensively studied before and the main cause is still yet unknown. The goal of this study was to analyze what factors that could be used to predict appendix perforation. This study was a case control study using 2013-2014 medical records in Al-Ihsan Hospital Bandung Regency as data. Case group pooled from 36 perforated appendix adult (above 15 years old) patients, while control group pooled from 93 non perforated appendix adult patients. Data analysis conducted were descriptive, chi-square, receiver operating characteristic, and multivariate logistic regression. There were two prediction factors which significantly associated with perforated appendix. Those were body temperature above $37.5^{\circ} \mathrm{C}$ with odds ratio (OR) 7.54 (95\% CI: 2.01-28.33), and leucocytes count above 11,500/ $\mathrm{mm}^{3}$ with OR 12.12 (95\% CI: 4.03-36.48). Further studies and body temperature validation on each hospital are needed to find other prediction factors, preparing pre operative equipment for immediate definite measure like surgery to prevent the complication of perforated appendix, and education to people that abdominal pain is not always causing by gastric problem and it might be a case of emergency.
\end{abstract}

Key words: Acute appendicitis, perforated appendix, predictive factors

Korespondensi: E-mail: fajar@unisba.ac.id 


\section{Pendahuluan}

Apendisitis akut merupakan peradangan yang terjadi di apendiks vermiformis dan merupakan penyebab tersering nyeri akut abdomen serta menghasilkan jenis operasi yang paling sering dilakukan di dunia. ${ }^{1}$ Apendisitis akut mampu berkembang menjadi perforasi apendiks yang nantinya dapat mengakibatkan $67 \%$ kematian padakasus-kasus apendisitis akut. ${ }^{2}$ Apendektomi yang dini telah lama direkomendasikan sebagai pengobatan apendisitis akut dikarenakan risiko progresivitas apendisitis menuju pada perforasi. ${ }^{3}$ Perforasi apendiks akan menyebabkan sepsis yang tidak terkontrol (akibat peritonitis), abses intra-abdomen atau septikemia gram negatif. ${ }^{4}$ Penelitian ini bertujuan mengetahui hubungan antara faktor-faktor yang dapat memberikan prediksi perforasi apendiks terhadap penderita apendisitis akut berusia di atas 15 tahun di RS Al-Ihsan Kabupaten Bandung.

\section{Metode Penelitian}

Penelitian ini merupakan penelitian analitik dengan rancangan desain studi kasus kontrol.
Populasi sumber penelitian ini adalah pasien apendisitis akut dewasa ( $\geq 15$ tahun) di RS AlIhsan Kota Bandung periode Januari2013sampai Juni 2014. Sampel diambil dari rekam medis pasien yang memenuhi kriteria inklusi, diambil dari tahun terdekat ke tahun terjauh. Kriteria inklusi kasus adalah pasien dewasa yang berusia di atas 15 tahun yang didiagnosis apendisitis akut, mendapatkan terapi apendektomi, dan didiagnosis pascaoperasi perforasi apendiks. Kriteria inklusi pada grup kontrol adalah pasien dewasa di atas 15 tahun, didiagnosis apendisitis akut, telah mendapatkan terapi apendektomi, dan didiagnosis pascaoperasi bukan sebagai perforasi apendiks. Kriteria eksklusi kedua grup adalah data rekam medis yang tidak lengkap. Teknik pengambilan sampel dilakukan secara konsekutif dengan jumlah yang minimal sampel berdasarkan rumus penentuan hipotesis odds ratio tidak sama dengan satu. Jumlah subjek yang diperlukan dalam penelitian ini pada grup kasus minimal sebanyak 28 subjek dan grup kontrol minimal sebanyak 84 subjek. Variabel yang diukur terdiri atas variabel tergantung, yaitu integritas apendiks (perforasi atau tidak) yang dinilai secara makroskopis lewat temuan operasi. Variabel bebas yang diukur adalah

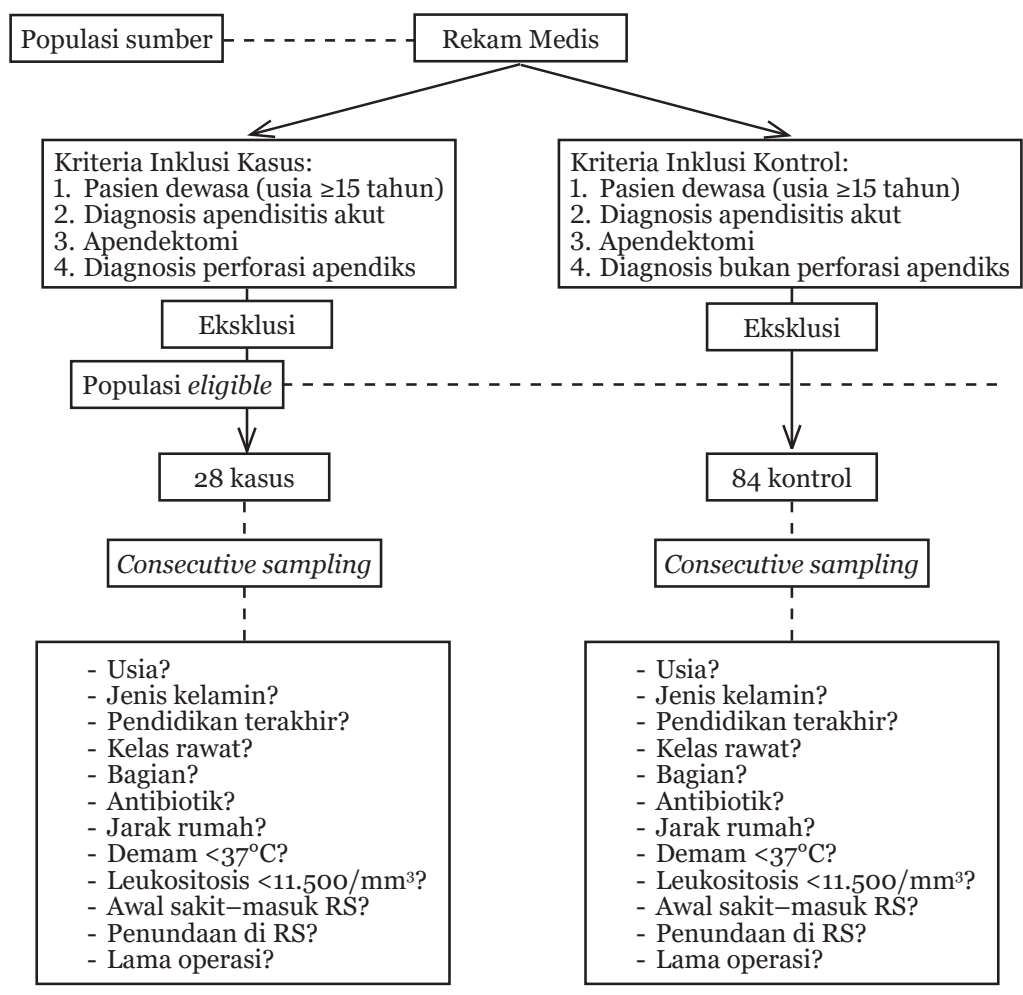

Gambar 1 Teknik Pengambilan Sampel 
Tabel 1 Distribusi Frekuensi Kasus dan Kontrol berdasarkan Faktor-faktor Prediksi Variabel Kontinus

\begin{tabular}{|c|c|c|c|c|c|c|c|}
\hline \multirow{2}{*}{ Faktor Prediksi } & \multicolumn{3}{|c|}{ Kasus } & \multicolumn{3}{|c|}{ Kontrol } & \multirow{2}{*}{ Satuan } \\
\hline & Median & Mean & St. Dev & Median & Mean & St. Dev & \\
\hline Usia & 31 & 31,94 & 13,13 & 27 & 29,78 & 13,66 & Tahun \\
\hline $\begin{array}{l}\text { Jarak wilayah tempat } \\
\text { tinggal ke RS }\end{array}$ & 9 & 11,79 & 9,66 & 10,4 & 12,45 & 12,34 & $\mathrm{Km}$ \\
\hline $\begin{array}{l}\text { Awal sakit sampai } \\
\text { operasi }\end{array}$ & 3 & 4,25 & 2,93 & 5 & 5,71 & 3,88 & Hari \\
\hline Lama operasi & 60 & 62,64 & 13,11 & 45 & 49,05 & 17,17 & Menit \\
\hline
\end{tabular}

usia, jenis kelamin, pendidikan terakhir, kelas rawat, masuk melalui bagian mana, pemberian antibiotik, jarak rumah menuju RS, suhu badan, jumlah leukosit, awal sakit hingga masuk RS, penundaan operasi di RS, dan lama operasi. Analisis yag dilakukan terdiri atas tiga tahap, yaitu analisis univariat, bivariat, dan multivariat. Analisis statistik univariat yang dilakukan adalah deskripsi proporsi untuk variabel kategorik dan distribusi frekuensi untuk variabel numerik. Analisis bivariat dilakukan uji chi-square atau uji Fisher exact dilanjutkan perhitungan odds ratio. Analisis multivariat yang cocok digunakan adalah regresi logistik berganda. Regresi logistik berganda ini merupakan perangkat statistik yang digunakan untuk menganalisis hubungan sebuah paparan dengan penyakit serta secara serentak untuk mengontrol pengaruh beberapa variabel perancu.

\section{Hasil Penelitian}

Dalam grup kasus terdapat usia yang lebih tua, jarak tempat tinggal yang lebih pendek, lama sakit yang lebih pendek, dan waktu operasi yang lebih lama dibanding dengan grup kontrol. Beberapa variabel numerik lalu diubah menjadi variabel kategorik sesudah ditentukan cut-off point melalui analisis receiver operating curve (ROC).

Disimpulkan bahwa suhu badan (area under ROC/AUROC 76\%), jumlah leukosit (AUROC 86\%), dan lama operasi (AUROC 74\%) dapat membedakan dengan baik perforasi apendiks dari apendisitis akut tanpa perforasi apendiks. Variabel lain (usia, jarak tempat tinggal, dan durasi sakit) tidak dapat membedakan perforasi dan nonperforasi apendiks.

Analisis ROC suhu badan memperlihatkan bahwa titik potong probabilitas pada kisaran o,20 dengan suhu badan $36,5^{\circ} \mathrm{C}$ (sensitivitas $63 \%$ dan spesifisitas $72 \%$ ). Suhu badan $36,5^{\circ} \mathrm{C}$ merupakan suhu badan pada manusia normal sehingga cut-off point yang digunakan adalah $37,5^{\circ} \mathrm{C}$ dengan sensitivitas $50 \%$ dan spesifisitas $91,40 \%$.

Analisis ROC jumlah leukosit menunjukkan titik potong probabilitas pada kisaran 0,27 dengan jumlah leukosit 11.500/ $\mathrm{mm}^{3}$ (sensitivitas $76 \%$ dan spesifisitas $81 \%$ ).

Analisis ROC durasi operasi menunjukkan titik potong probabilitas pada kisaran 0,35 dengan lama operasi yang didapat adalah 50 menit (sensitivitas 57\% dan spesifisitas 83\%).

Proporsi faktor prediksi perforasi apendiks yang lebih banyak terdapat dalam grup kasus adalah usia kurang dari 55 tahun (97\%), dirawat di kelas III (58\%), masuk melalui UGD (86\%), diberikan antibiotik (67\%), tidak demam (56\%), jumlah leukosit di atas $11.500 / \mathrm{mm}^{3}$ (86\%), dan lama operasi di atas 50 menit (86\%).

Variabel yang memiliki hubungan dengan perforasi apendiks adalah masuk melalui bagian mana, pemberian antibiotik, suhu badan, jumlah leukosit, lama operasi.

Semua faktor prediksi mempunyai $\mathrm{r}<0,8 \mathrm{O}^{5}$ memperlihatkan bahwa antara faktor-faktor prediksi tidak memiliki kolinearitas sehingga dapat dimasukkan ke dalam model awal prediksi perforasi apendiks pada penderita apendisitis akut.

Model akhir didapatkan dari backward selection setelah mengeliminasi faktor prediksi yang tidak signifikan dengan membandingkan model satu dan lainnya menggunakan likelihood ratio test. ${ }^{6}$

Lamanya operasi merupakan variabel yang dipengaruhi oleh perforasi. Secara logika begitu 
Tabel 2 Distribusi Frekuensi Kasus dan Kontrol Seluruh Faktor Prediksi

\begin{tabular}{|c|c|c|c|c|}
\hline \multirow{2}{*}{ Faktor Prediksi } & \multicolumn{2}{|c|}{ Kasus } & \multicolumn{2}{|c|}{ Kontrol } \\
\hline & $\mathbf{n}$ & $\%$ & $\mathbf{n}$ & $\%$ \\
\hline \multicolumn{5}{|l|}{ Usia (tahun) } \\
\hline$>55$ & 1 & 3 & 4 & 4 \\
\hline$\leq 55$ & 35 & 97 & 89 & 96 \\
\hline \multicolumn{5}{|l|}{ Jenis kelamin } \\
\hline Laki-laki & 18 & 50 & 34 & 37 \\
\hline Perempuan & 18 & 50 & 59 & 63 \\
\hline \multicolumn{5}{|l|}{ Kelas rawat } \\
\hline Kelas di atas kelas III & 15 & 42 & 45 & 48 \\
\hline Kelas III & 21 & 58 & 48 & 52 \\
\hline \multicolumn{5}{|l|}{ Masuk melalui } \\
\hline Poliklinik & 5 & 14 & 49 & 53 \\
\hline UGD & 31 & 86 & 44 & 47 \\
\hline \multicolumn{5}{|l|}{ Pemberian antibiotik } \\
\hline $\mathrm{Ya}$ & 24 & 67 & 34 & 37 \\
\hline Tidak & 12 & 33 & 59 & 63 \\
\hline \multicolumn{5}{|l|}{ Suhu badan } \\
\hline $\operatorname{Demam}\left(>37,5^{\circ} \mathrm{C}\right)$ & 16 & 44 & 4 & 4 \\
\hline Tidak demam $\left(\leq 37,5^{\circ} \mathrm{C}\right)$ & 20 & 56 & 89 & 96 \\
\hline \multicolumn{5}{|l|}{ Jumlah leukosit } \\
\hline$\geq 11.500 / \mathrm{mm}^{3}$ & 31 & 86 & 23 & 25 \\
\hline$<11.500 / \mathrm{mm}^{3}$ & 5 & 14 & 70 & 75 \\
\hline \multicolumn{5}{|l|}{ Lama masuk-operasi } \\
\hline$>12$ jam & 18 & 50 & 56 & 60 \\
\hline$\leq 12$ jam & 18 & 50 & 37 & 40 \\
\hline
\end{tabular}

perforasi apendiks terjadi, timbul kontaminasi dalam dinding perut sehingga waktu operasi akan menjadi lebih lama. Karena lama operasi merupakan akibat dari perforasi maka lama operasi dieliminasi secara substansi.

\section{Pembahasan}

Hasilanalisis tidak menunjukkan hubunganyang signifikan antara usia dan perforasi apendiks. Perbedaan karakteristik subjek penelitian yang dilakukan Jaffe dan Berger ${ }^{4}$ dibanding dengan penelitian ini kemungkinan menyebabkan hasil yang berbeda. Penelitian yang dilakukan di RS Al-Ihsan di Kabupaten Bandung menunjukkan bahwa penderita apendisitis akut lebih banyak berjenis kelamin perempuan dibanding dengan laki-laki, sedangkan perbandingan jenis kelamin pada perforasi apendiks terdapat dalam jumlah yang sama. Teknik pengambilan sampel secara konsekutif(non-probability)dalampenelitianini tidak mencerminkan kemungkinan sebenarnya mengenai perbandingan jenis kelamin dalam grup perforasi dan grup nonperforasi. Perforasi 
Tabel 3 Hubungan antara Faktor Prediksi dengan Perforasi Apendiks

\begin{tabular}{|c|c|c|c|c|c|}
\hline Faktor Prediksi & Kasus & Kontrol & OR & IK 95\% & $\mathbf{p}$ \\
\hline \multicolumn{6}{|l|}{ Usia (tahun) } \\
\hline$>55$ & 1 & 4 & \multirow[t]{2}{*}{0,64} & \multirow[t]{2}{*}{$0,01-6,74$} & \multirow[t]{2}{*}{1,00} \\
\hline$\leq 55$ & 35 & 89 & & & \\
\hline \multicolumn{6}{|l|}{ Jenis kelamin } \\
\hline Laki-laki & 18 & 34 & \multirow{2}{*}{1,74} & \multirow{2}{*}{$0,74-4,05$} & \multirow[t]{2}{*}{0,17} \\
\hline Perempuan & 18 & 59 & & & \\
\hline \multicolumn{6}{|l|}{ Masuk lewat } \\
\hline Poliklinik & 5 & 49 & \multirow{2}{*}{0,14} & \multirow{2}{*}{$0,04-0,43$} & \multirow[t]{2}{*}{0,0001} \\
\hline UGD & 31 & 44 & & & \\
\hline \multicolumn{6}{|l|}{ Antibiotik } \\
\hline $\mathrm{Ya}$ & 24 & 23 & \multirow{2}{*}{3,47} & \multirow{2}{*}{$1,43-8,58$} & \multirow[t]{2}{*}{0,0029} \\
\hline Tidak & 12 & 42 & & & \\
\hline \multicolumn{6}{|l|}{ Kelas rawat } \\
\hline Kelas di atas kelas III & 15 & 45 & \multirow{2}{*}{0,76} & \multirow{2}{*}{$0,32-1,77$} & \multirow[t]{2}{*}{0,56} \\
\hline Kelas III & 21 & 48 & & & \\
\hline \multicolumn{6}{|c|}{ Lama masuk RS-operasi } \\
\hline$>12$ jam & 18 & 56 & \multirow{2}{*}{0,66} & \multirow{2}{*}{$0,28-1,54$} & \multirow[t]{2}{*}{0,36} \\
\hline$\leq 12$ jam & 18 & 37 & & & \\
\hline \multicolumn{6}{|l|}{ Suhu badan } \\
\hline$>37,5^{\circ} \mathrm{C}$ & 16 & 4 & \multirow[t]{2}{*}{17,8} & \multirow[t]{2}{*}{$4,89-78,63$} & \multirow[t]{2}{*}{0,00} \\
\hline$\leq 37,5^{\circ} \mathrm{C}$ & 20 & 89 & & & \\
\hline \multicolumn{6}{|l|}{ Jumlah leukosit } \\
\hline$\geq 11.500$ & 31 & 23 & \multirow[t]{2}{*}{18,6} & \multirow[t]{2}{*}{$6,04-66,69$} & \multirow[t]{2}{*}{0,0000} \\
\hline$<11.500$ & 5 & 69 & & & \\
\hline Lama operasi & & & & & \\
\hline$\geq 50$ menit & 31 & 42 & 7,53 & $2,55-26,61$ & 0,00 \\
\hline$<50$ menit & 5 & 51 & & & \\
\hline
\end{tabular}

apendiks yang diteliti dalam penelitian ini tidak menunjukkan hubungan dengan kelas rawat secara langsung maupun status ekonomi secara tidak langsung. Kemungkinan terdapat faktor lain yang lebih menentukan perforasi apendiks dibandingkan dengan status ekonomi dalam penelitian ini. Penundaan apendektomi menjadi faktor risiko terjadi perforasi apendiks seperti yang diteliti oleh Busch dkk. di Swiss. ${ }^{7}$ Penundaan $>12$ jam meningkatkan odds untuk terkena perforasi apendiks sebanyak 1,4 kali bila dibanding dengan penundaan $\leq 12$ jam. ${ }^{7}$ Berbeda dengan penundaan apendektomi di $\mathrm{RS}$ Al-Ihsan tidak berhubungan dengan risiko

Tabel 4 Model Akhir Hasil Analisis Regresi Logistik Multivariat Faktor Prediksi Perforasi Apendiks

\begin{tabular}{lccccc}
\hline \multicolumn{1}{c}{ Variabel } & B & Z & Sig & OR & IK 95\% OR \\
\hline Suhu badan & 2,02 & 2,99 & 0,003 & 7,54 & $2,01-28,33$ \\
Leukosit & 2,49 & 4,44 & 0,000 & 12,12 & $4,03-36,48$ \\
Konstanta & $-2,76$ & $-5,82$ & 0,000 & & \\
\hline
\end{tabular}

Logit $\mathrm{P}(\mathrm{X})=-2,76+2,02 \mathrm{X}_{\text {suhu badan }}+2,49 \mathrm{X}_{\text {leukosit }}$ 
Tabel 5 Probabilitas Perforasi Apendis Apabila Terdapat Faktor Prediksi

\begin{tabular}{lcc}
\hline \multicolumn{1}{c}{ Apendisitis Akut } & $\mathbf{Z}$ & Persen \\
\hline Tanpa demam, tanpa leukositosis & $-2,76$ & $6 \%$ \\
Demam (suhu badan $>37,5^{\circ} \mathrm{C}$ ), tanpa leukositosis & $-0,74$ & $32 \%$ \\
Leukositosis $>11.500 / \mathrm{mm}^{3}$ tanpa demam & $-0,27$ & $43 \%$ \\
Demam (suhu badan $>37,5^{\circ} \mathrm{C}$ ), leukositosis $>11.500 / \mathrm{mm}^{3}$ & 1,75 & $85 \%$ \\
\hline
\end{tabular}

perforasi apendiks. Penundaan yang terjadi di RS tidak terjadi dalam berhari-hari sehingga kemungkinan manifestasi perubahan mukosa apendiks tidak akan terjadi. Pelayanan di RS AlIhsan tidak memiliki hubungan yang signifikan dengan perforasi apendiks.

Analisis multivariat yang dilaksanakan pada penelitian ini memperlihatkan hasil hubungan yang signifikan suhu badan, leukosit, dan lama operasi dengan terjadinya perforasi apendiks. Penderita apendisitis akut dengan jumlah leukosit $>11.500 / \mathrm{mm}^{3}$ memiliki risiko 12,12 kali untuk mengalami perforasi apendiks setelah dikontrol oleh faktor peningkatan suhu badan. Penderita apendisitis akut dengan suhu $>36,5^{\circ} \mathrm{C}$ memiliki risiko 7,54 kali mengalami perforasi apendiks sesudah dikontrol oleh peningkatan jumlah sel leukosit. Perforasi apendiks menimbulkan reaksi berupa inflamasi peritoneal lewat kebocoran isi dari usus ke sekitar peritoneum. Peritoneum dipersarafi cabang saraf yang sama dengan yang mempersarafi dinding abdomen, sangat sensitif terhadap nyeri, panas, sentuhan, dan tekanan. ${ }^{8}$ Rasa nyeri hebat yang muncul ini akan membuat penderita untuk segera datang ke UGD. Jumlah leukosit yang tinggi menjadi pertimbangan bagi dokter untuk memberikan antibiotik pada saat admisi di UGD. Peningkatan suhu yang terjadi merupakan mekanisme adaptif untuk kontrol infeksi. Fenomena ini disebabkan oleh stimulus eksternal (biasanya mikrob) yang memicu fagosit untuk mengeluarkan hormon penyebab demam (pirogen endogen). Pirogen tersebut bersirkulasi ke area hipotalamus anterior dan preoptik yang meningkatkan set-point temperatur tubuh. ${ }^{9}$ Apendisitis berdasarkan atas patofisiologi akan menyebabkan disfungsi mukosa yang nantinya akan meningkatkan pertumbuhannya bakteri dan menimbulkan mekanisme adaptif berupa peningkatan suhu badan. ${ }^{4,9}$ Peningkatan suhu badan $>37,5^{\circ} \mathrm{C}$ memiliki risiko 4,84 kali untuk mengalami perforasi apendiks bila dibanding dengan suhu badan di bawahnya.

\section{Simpulan}

Proporsi faktor prediksi perforasi apendiks yang lebih banyak terdapat pada grup kasus adalah usia $<55$ tahun, dirawat di kelas III, masuk melalui UGD, diberikan antibiotik, tidak demam, jumlah leukosit $>11.500 / \mathrm{mm}^{3}$, dan lama operasi $>50$ menit.

Faktor prediksi yang paling dominan untuk perforasi apendiks adalah jumlah sel leukosit $>11.500 / \mathrm{mm}^{3}$ dengan risiko 12,12 kali dan suhu badan $>37,5^{\circ} \mathrm{C}$ dengan risiko 7,54 kali. Apabila penderita apendisitis akut mempunyai faktor prediksi jumlah sel leukosit $>11.500 / \mathrm{mm}^{3}$ dan suhu badan $>37,5^{\circ} \mathrm{C}$ kemungkinan mengalami perforasi apendiks sebesar $85 \%$.

\section{Ucapan Terima Kasih}

Penelitian ini berhasil dilakukan atas kerja sama berbagai pihak. Terima kasih penulis ucapkan untuk Allah SWT yang melancarkan jalannya penelitian, rekan-rekan peneliti yang ikut serta, pihak RS Al-Ihsan Kabupaten Bandung yang telah memberikan izin tempat penelitian, LPPM Unisba yang memberikan bantuan operasional penelitian, juga FKM UI yang telah membekali metode penelitian, dan pimpinan FK Unisba untuk kesempatan yang telah diberikan.

\section{Daftar Pustaka}

1. Penhold R, Chisolm D, Nwomeh B, Kelleher K. Geographic disparities in the risk of perforated appendicitis among children in Ohio: 2001-2003. Int $\mathrm{J}$ Health Geogr. 2008;7:56.

2. Heber FR. Perforating inflammation of the vermiform appendix: with special reference to its early diagnosis and treatment. Trans Assoc Am Physicians. 1886;1.

3. Alder AC, Fomby TB, Woodward WA, Haley RW, Sarosi G, Livingston EH. Association of 
viral infection and appendicitis. Arch Surg. 2010 Jan;145(1):63-71.

4. Jaffe BM, Berger DH. The appendix. Dalam: Brunicardi FC, Andersen DK, Billiar TR, Dunn DL, Hunter JG, Matthews JB, dkk., penyunting. Schwartz's principles of surgery. Edisi ke-9. Philadelphia: McGrawHill Co.; 2010.

5. Hastono SP. Analisis multivariat. Jakarta: FKM UI; 2006.

6. Kleinbaum DG, Klein M. Logistic regression: a self-learning text. Dalam: Gail M, Krickeberg K, Samet JM, Tsiatis A, Wong W., penyunting. Statistics for biology and health. Edisi ke-3. New York: Springer;
2010. hlm. 218.

7. Busch M, Gutzwiller FS, Aellig S, Kuettel R, Metzger U, Zingg U. In-hospital delay increases the risk of perforation in adults with appendicitis. World J Surg. 2011 Jul;35(7):1626-33.

8. Abou-Nukta F, Bakhos C, Arroyo K, Koo Y, Martin J, Reinhold R, dkk. Effects of delaying appendectomy for acute appendicitis for 12 to 24 hours. Arch Surg. 2006 May;141(5):504-6.

9. Bernheim HA, Block LH, Atkins E. Fever: pathogenesis, pathophysiology, and purpose. Ann Intern Med. 1979 Aug;91(2):261-70. 